Original article

\title{
Interactions between industrial development and environmental protection dimensions of Sustainable Development Goals (SDGs): Evidence from 40 countries
} with different income levels

\author{
Suyu Liu
}

United Nations Industrial Development Organization, Vienna International Centre, Vienna, Austria

E-mail address: suyu.liu@linacre.ox.ac.uk

ORCID iD:: https://orcid.org/0000-0003-4966-8047

\begin{abstract}
This article explores the interactions between industrial development and environmental protection dimensions of Sustainable Development Goals (SDGs). In consideration of the suitability and data availability, this article uses the SDG indicators 9.2.1 (manufacturing value-added per capita) and 12.4.1 (E-waste per capita) as the two indicators to reflect industrial development and environmental protection under the SDGs framework. Based on a cross-country data source, this article examines the correlation between manufacturing value-added per capita and E-waste per capita in forty countries across four income levels as defined by the World Bank. The results show that the manufacturing value-added per capita and E-waste per capita increase with the countries' income levels. In addition, the positive correlation between manufacturing value-added per capita and electronic waste (E-waste_per capita) becomes weaker with the increase of the countries' income levels, and for high-income countries the correlation turns negative. This provides evidence to partially support the Environmental Kuznets Curve, which demonstrates the 'inverted-U shape' relationship between economic development and environmental protection. It also generates a number of implications on the monitoring and management of SDG indicators. In consideration of the interactions between different SDGs (including targets and indicators), a holistic, multi-disciplinary, and cross-departmental management and monitoring of SDG indicators is recommended.
\end{abstract}

KEY WORDS: Sustainable Development Goals; manufacturing value-added; E-waste; interactions; Environmental Kuznets Curve

ARTICLE HISTORY: received 9 July 2020; received in revised form 20 August 2020; accepted 27 August 2020

\section{Introduction}

A group of 17 Sustainable Development Goals (SDGs) were adopted as the core component of the 2030 Agenda for Sustainable Development by the United Nations (UN) in 2015. The 17 SDGs cover a number of the main dimensions of sustainable development such as industrial development, environmental protection, and human wellbeing. The SDGs become UN member states' international commitments to contributing to global sustainable development (DIAS ET AL., 2018). Also, SDGs have started to become used as guidance for research and practice in sustainable development (BIERMANN ET AL., 2017).

The SDGs can be classified into three categories. The first category includes the 17 goals across various fields of sustainable development. Under the 17 goals, there are currently 159 targets which were to be achieved by 2030 or earlier. The third category currently consists of 247 specific indicators (including 231 unique indicators and 12 indicators which repeat two or more times) which monitor the progress towards the 159 targets. The 17 goals are fixed while the targets and indicators may be added, removed, and/or modified by the UN 
Statistical Commission. The data of SDG indicators are presented by UN Statistics Division via the Global SDG Indicators Database. However, the monitoring of, and data collection for, many SDG indicators are conducted by different UN agencies and/or departments ('custodian agencies'). For example, the custodian agency for most indicators under SDG 9 is the United Nations Industrial Development Organization (UNIDO), and the custodian agency for most indicators under SDG 12 is the United Nations Environment Programme (UNEP).

As a consequence of the rapid growth of the electronics and telecommunications industry, the volume of electronic waste (E-waste) has increased sharply. For example, in 2014, the estimated annual amount of E-waste was around 41.8 million metric tons (BALDÉ ET AL., 2015, p. 4). However, the E-waste management of many stakeholders (e.g. bulk consumers) has not been strongly linked with sustainability strategies. Therefore, the E-waste generation per capita has been selected as a parameter to monitor each country's progress in E-waste generation and management, under the SDG indicator 12.4.1. It is also a widely-used indicator to reflect a country's progress in environmentally friendly production and practice in recycling and legislation (KUMAR ET AL., 2017).

Manufacturing value-added (MVA) per capita is a parameter which benchmarks the industrial performance of each country with consideration of the population size. With the rapid industrialization and upgrade to Industry 4.0, MVA per capita is accepted as a parameter to measure each country's industrial development and sustainability under the SDG indicator 9.2.1. Therefore, exploration of the interlinkages between MVA per capita and E-waste per capita can reflect the interaction between the industrial development and environmental protection dimensions of SDGs.

Previous studies have made contributions to investigating the interactions, integrations, tradeoffs and prioritizations betweeng different SDG indicators, including indicators of industrial development and environmental protection. For many scholars, the SDGs (including relevant targets and indicators) are an integrated framework and the indicators are inter-linked with each other. For example, LE BLANC (2015) argues that the SDGs as a whole can be considered as an integrated system, in which targets and indicators are associated so that policy integration across sectors may be facilitated. DIAS ET AL. (2018) also suggest that SDGs function as a network of targets and the goals are inter-related. Realizing the integrated and inter-related nature of SDGs, SACHS ET AL. (2019) argue that achieving SDGs will require transformations across all sectors and the complementary efforts from different stakeholders such as government, non-governmental organizations (NGOs), business, and researchers. SCHROEDER ET Al. (2019) demonstrate that a circular economy could be a suitable synergy across SDGs and would address the possible trade-offs between different SDGs. Noticing the interdisciplinary nature of sustainable development, DIAZ-SARACHAGA ET AL. (2018) also developed a composite SDG index to measure progress towards the 2030 Agenda for Sustainable Development.

With special attention to industrial development and environmental protection, the International Council for Science (ICSU) and the International Social Science Council (ISSC) (2015) found that SDG 9 has the most important linkages with three goals directly related to environmental protection: SDGs 11,12, and 13. This is because the development and organization of infrastructure and industry, as reflected by SDG 9, largely determine the use of resources, consumption, and waste management as measured by the three SDGs, especially SDG 12 . Similarly, ICSU and ISSC (2015) argue that sustainable consumption and production, as measured by SDG 12, is directly associated with SDG 9 which evaluates the provision of essential industrial and constructional goods and services. However, it has not explored the interactions between specific indicators under SDGs 9 and 12, which provides spaces for this article.

It is also essential to emphasize that not all researchers agree that SDGs (including relevant targets and indicators) are integrated and compatible with each other. On the contrary, some scholars believe that different SDGs and related targets and indicators have trade-offs among each other and were given different prioritizations in practice. For example, NILSSON ET AL. (2017, p. 22) argue that '...interactions between SDGs currently have a weak conceptual and scientific underpinning...', although the 2030 Agenda for Sustainable Development is often considered as a whole. This could be a reason for the trade-offs between different SDGs. NILSSON ET AL. (2017, p. 21) further argue that countries may prioritize some goals over others due to practical considerations. This is supported by TOSUN \& LEININGER (2017), who use national level evidence to demonstrate that '...the links among the different goals and the idea of policy integration are subject to divergent interpretations' (Tosun \& LEININGER, 2017, p. 1). With a case study of a small island country, ADSHEAD ET AL. (2019) describe the trade-offs between indicators when making investment and policy intervention decisions. 
Such trade-offs and prioritizations are also related to the interdisciplinary nature of SDGs (DIAZ-SARACHAGA ET AL., 2018; LIU, 2020), and the complicated political process including international negotiations (HÁK ET AL., 2016; NILSSON ET AL., 2016).

Although previous studies have contributed tremendously to the knowledge of SDGs and their interactions, significant shortcomings still exist. Firstly, the history of SDGs is only around 5 years and therefore the integration, interaction, and trade-off between SDGs are still under-researched. Secondly, the empirical studies on SDGs and the interactions between different SDGs (including targets and indicators) are also limited due to data restrictions, especially for resource and environmental protection indicators (LUKEN ET AL., 2020). Thirdly, even though the regional disparities in SDG performance have been noted (DIAZ-SARACHAGA ET AL., 2018), there is little research about the interaction between SDG indicators of industrial development and environmental protection. Therefore, to bridge the literature gap, this article explores the interaction between MVA per capita (SDG indicator 9.2.1) and E-waste per capita (SDG indicator 12.4.1) according to the income level of countries. More specifically, this artcile answers two questions: (1) are MVA per capita and E-waste per capita negatively associated with each other, as higher MVA per capita usually indicate higher technology-intensive and greener industrial production? (2) Do the associations between MVA per capita and E-waste per capita vary across countries with different income levels?

\section{Materials and methods}

\subsection{Data}

The data measuring SDG indicators 9.2.1 and 12.4.1 are obtained from the Global SDG Indicators Database presented by the UN Statistics Division. In consideration of the data availability, this article uses the 2017 data for MVA per capita and E-waste per capita, as the 2017 data is the most recent available data for E-waste per capita. The measurement unit for MVA per capita is 2015 constant US Dollar (USD), and for E-waste per capita is kilo (kg). The standardized measurement units bring conveniences for cross-country comparisons.

Forty countries are selected according to their income levels as defined by the WORLD BANK (2020). For each of the four income levels: low-income economies, lower-medium-income economies, upper-medium-income economies, and high-income economies, ten countries are selected. To reduce the widely known disturbances by top highincome countries (the 'outlier effect'), this article did not choose any top-10 country from the UNIDO Competitiveness Industrial Performance Index (UNIDO, 2019). Unselecting the top highincome countries is a common practice to reduce the possible outlier effect when analyzing the impact of a country's development levels on SDGs, as these top high-income and highly industrialized economies outperform other countries (KYNČLOVÁ ET AL., 2020). A number of other factors such as data availability and geographic representativeness are also considered in the selection of the forty countries.

The data has its advantages and limitations. The wide geographic coverage of the SDG database enables suitable cross-country comparisons. This is particularly the situation as international standards and methods are progressively accepted by national statistical systems. For example, the International Standard Industrial Classification of All Economic Activities (ISIC), which is the foundation of defining the scope of manufacture and MVA, has been incorporated into the national statistical systems of most countries. However, it should be noted that due to the sharp differences in the national context, the integration of international standards and methods into national statistical systems may vary across countries. In addition, the disparities of statistical capacity in different countries may have impact on the data quality. For example, in countries which have relatively weaker statistical capacity, the estimation and reporting of data may be less reliable. This is actually another topic covered by SDG Indicators 17.18.2 and 17.18.3, which is interesting, but beyond the scope of this article.

\subsection{Methods}

SDG indicators 9.2.1 and 12.4.1 reflect two main aspects of sustainable development. SDG indicator 9.2.1 provides measurement of SDG 9 'Build resilient infrastructure, promote inclusive and sustainable industrialization and foster innovation' via raising industry's share in GDP (as described by SDG Target 9.2). SDG indicator 12.4.1 is a measurement of SDG 12 'Ensure sustainable consumption and production patterns' through evaluating the progress of achieving environmentally sound management of chemicals and all wastes (as described by SDG Target 12.4). These two indicators are also versatile because they can be used for measuring other objectives. For example, SDG indicator 9.2.1 can also be used to measure the level of industrialization and even 
the level of economic development of countries due to the widely-perceived association between industrial development and economic growth (OUYANG \& Fu, 2012).

To analyze the interactions between SDG indicators 9.2.1 and 12.4.1, this article uses correlation analysis between MVA per capita and E-waste per capita in the forty selected countries. At first, an overall correlation was conducted to explore the relationship between MVA per capita and E-waste per capita in all the forty selected countries. Then the correlations were run in each of the ten countries according to the four income levels. This generated more detailed evidence of whether the interactions between different SDG indicators are associated with income levels of countries. Correlation analysis is an often used method when exploring the relationship between SDG indicators (e.g. KYNČLOVÁ ET AL., 2020) due to its simplicity and convenience for data presentation and visualization. This article reports Pearson's $r$ values of the correlations because the data for the two SDG indicators were both linear and numerical.

\section{Results and Analysis}

\subsection{Overall analysis}

As shown in Tables 1 and 2, for the forty selected countries, there was a significant and positive correlation between MVA per capita and E-waste per capita. That means, if the income levels were not considered, a country with higher MVA per capita generates more E-waste per capita. This does not provide evidence to support the hypothesis that a higher level of industrialization will lead to greener production and consumption, as often assumed about the relationship between industrial development and environmental protection SDG indicators. However, Table 1 shows that the variations in MVA and E-waste per capita across countries are quite substantial, which is also a reason for this article to proceed with further analysis based on income levels of countries.

Table 1. Descriptive data (overall)

\begin{tabular}{|l|c|c|}
\hline \multicolumn{1}{|c|}{ Country } & $\begin{array}{c}\text { MVA per } \\
\text { capita (2015 } \\
\text { constant USD) }\end{array}$ & $\begin{array}{c}\text { E-waste } \\
\text { per capita } \\
\text { (kg) }\end{array}$ \\
\hline Afghanistan & 68.8 & 0.63 \\
\hline Angola & 283.9 & 4.15 \\
\hline Argentina & 1803.8 & 10.31 \\
\hline Australia & 2835.5 & 21.68 \\
\hline Bahrain & 3632.6 & 15.92 \\
\hline Bangladesh & 310.3 & 1.19 \\
\hline
\end{tabular}

\begin{tabular}{|c|c|c|}
\hline Belarus & 1427.2 & 9.33 \\
\hline Bolivia & 346.1 & 3.57 \\
\hline Bulgaria & 1205.2 & 11.74 \\
\hline Cambodia & 246.8 & 1.14 \\
\hline Cameroon & 209.2 & 1.03 \\
\hline Chile & 1520.9 & 9.93 \\
\hline Czechia (Czech Republic) & 5404.1 & 15.71 \\
\hline Ethiopia & 57.8 & 0.58 \\
\hline Fiji & 537.4 & 6.07 \\
\hline Ghana & 242.2 & 1.75 \\
\hline Guinea-Bissau & 67.6 & 0.54 \\
\hline Honduras & 436.7 & 2.59 \\
\hline Israel & 4824.3 & 14.53 \\
\hline Jordan & 764.3 & 5.45 \\
\hline Kazakhstan & 1159.4 & 9.17 \\
\hline Kuwait & 2265.3 & 15.83 \\
\hline Lithuania & 3121.8 & 12.3 \\
\hline Madagascar & 30.4 & 0.57 \\
\hline Malawi & 36.5 & 0.48 \\
\hline Mongolia & 357.3 & 5.19 \\
\hline Nepal & 48.5 & 0.93 \\
\hline New Zealand & 4447.3 & 19.19 \\
\hline Nigeria & 232.9 & 2.32 \\
\hline Peru & 830.9 & 6.28 \\
\hline Republic of Moldova & 214.6 & 4.00 \\
\hline Russian Federation & 1226.8 & 11.34 \\
\hline Rwanda & 50.8 & 0.57 \\
\hline Saudi Arabia & 2753.7 & 17.57 \\
\hline Slovakia & 4172.4 & 12.76 \\
\hline Thailand & 1772.4 & 9.15 \\
\hline Trinidad and Tobago & 2328.1 & 15.73 \\
\hline Uganda & 57.6 & 0.80 \\
\hline Yemen & 83.1 & 1.52 \\
\hline Zimbabwe & 81.4 & 1.08 \\
\hline Mean (StD) & $\begin{array}{r}1287.4 \\
(1519.2)\end{array}$ & $\begin{array}{r}7.11 \\
(6.36)\end{array}$ \\
\hline
\end{tabular}

(Note: The measurement units of MVA per capita and E-waste per capita are constant throughout this paper; names of countries or territories used in this article does not reflect any opinion on the legal status or boundaries of any country and/or territory)

Table 2. Correlation results

\begin{tabular}{|l|c|c|}
\hline & $\begin{array}{c}\text { MVA } \\
\text { per capita }\end{array}$ & $\begin{array}{c}\text { E-waste } \\
\text { per capita }\end{array}$ \\
\hline Pearson's r (coefficient) & 1 & $0.873^{* * *}$ \\
\hline P-value & -- & 0.00 \\
\hline
\end{tabular}

(In this paper, ${ }^{* * *}$ indicates significance at 0.01 level and ${ }^{* *}$ indicates significance at 0.05 level) 


\subsection{Analysis based on different income levels}

Tables 3 and 4 contain the data and results of the correlations between MVA per capita and E-waste per capita for the selected ten low-income countries. The results suggest that MVA per capita and E-waste per capita in low-income countries are positively and significantly associated with each other. That means, the higher level of industrialization is linked with more E-waste per capita. The correlation coefficient is 0.663 , which indicates the correlation is strong. The averages of MVA per capita and E-waste per capita of the ten selected countries are both low, which stand as 58.3 USD and 0.77 kilo respectively.

Table 3. Descriptive data (low-income countries)

\begin{tabular}{|l|c|c|}
\hline \multicolumn{1}{|c|}{ Country } & $\begin{array}{c}\text { MVA } \\
\text { per capita }\end{array}$ & $\begin{array}{c}\text { E-waste } \\
\text { per capita }\end{array}$ \\
\hline Afghanistan & 68.8 & 0.63 \\
\hline Ethiopia & 57.8 & 0.58 \\
\hline Guinea-Bissau & 67.6 & 0.54 \\
\hline Madagascar & 30.4 & 0.57 \\
\hline Malawi & 36.5 & 0.48 \\
\hline Nepal & 48.5 & 0.93 \\
\hline Rwanda & 50.8 & 0.57 \\
\hline Uganda & 57.6 & 0.80 \\
\hline Yemen & 83.1 & 1.52 \\
\hline Zimbabwe & 81.4 & 1.08 \\
\hline Mean (StD) & $58.3(17.5)$ & $0.77(0.33)$ \\
\hline
\end{tabular}

Table 4. Correlation results

\begin{tabular}{|l|c|c|}
\hline & $\begin{array}{c}\text { MVA } \\
\text { per capita }\end{array}$ & $\begin{array}{c}\text { E-waste } \\
\text { per capita }\end{array}$ \\
\hline Pearson's r & 1 & $0.663^{* *}$ \\
\hline P-value & -- & 0.037 \\
\hline
\end{tabular}

Tables 5 and 6 report the correlation results of MVA per capita and E-waste per capita in the selected ten lower-middle-income countries. Although there is still a positive correlation between SDG indicators 9.2.1 and 12.4.1 as measured by MVA per capita and E-waste per capita respectively, the correlation is weak (coefficient is only 0.341 ) and not statistically significant. That means, in lower-middle-income countries, the association between MVA per capita and E-waste per capita is positive, but such association is not as strong as in low-income countries. The average MVA per capita and E-waste per capita of the ten selected countries are 288 USD and $2.69 \mathrm{~kg}$ respectively, which are both much higher than in the selected low-income countries.
Table 5. Descriptive data (lower-middle-income countries)

\begin{tabular}{|l|c|c|}
\hline \multicolumn{1}{|c|}{ Country } & $\begin{array}{c}\text { MVA } \\
\text { per capita }\end{array}$ & $\begin{array}{c}\text { E-waste } \\
\text { per capita }\end{array}$ \\
\hline Angola & 283.9 & 4.15 \\
\hline Bangladesh & 310.3 & 1.19 \\
\hline Bolivia & 346.1 & 3.57 \\
\hline Cameroon & 209.2 & 1.03 \\
\hline Cambodia & 246.8 & 1.14 \\
\hline Ghana & 242.2 & 1.75 \\
\hline Honduras & 436.7 & 2.59 \\
\hline Mongolia & 357.3 & 5.19 \\
\hline Republic of Moldova & 214.6 & 4.00 \\
\hline Nigeria & 232.9 & 2.32 \\
\hline Mean (StD) & $288.0(74.0)$ & $2.69(1.46)$ \\
\hline
\end{tabular}

Table 6. Correlation results

\begin{tabular}{|l|c|c|}
\hline & $\begin{array}{c}\text { MVA } \\
\text { per capita }\end{array}$ & $\begin{array}{c}\text { E-waste } \\
\text { per capita }\end{array}$ \\
\hline Pearson's r & 1 & 0.341 \\
\hline P-value & -- & 0.336 \\
\hline
\end{tabular}

For the ten selected upper-middle-income countries (Table 7), the correlation between MVA per capita and E-waste per capita becomes positive and significant again. As revealed in Table 8, the correlation coefficient is 0.693 , which indicates a strong and positive correlation between SDG indicators 9.2.1 and 12.4.1. Furthermore, Table 7 shows that the mean values of MVA per capita and E-waste per capita are 1224.8 USD and 8.88 $\mathrm{kg}$ respectively, which are much higher than the low-income and lower-middle-income countries.

Table 7. Descriptive data (upper-middle-income countries)

\begin{tabular}{|l|c|c|}
\hline \multicolumn{1}{|c|}{ Country } & $\begin{array}{c}\text { MVA } \\
\text { per capita }\end{array}$ & $\begin{array}{c}\text { E-waste } \\
\text { per capita }\end{array}$ \\
\hline Argentina & 1803.8 & 10.31 \\
\hline Belarus & 1427.2 & 9.33 \\
\hline Bulgaria & 1205.2 & 11.74 \\
\hline Fiji & 537.4 & 6.07 \\
\hline Jordan & 764.3 & 5.45 \\
\hline Kazakhstan & 1159.4 & 9.17 \\
\hline Chile & 1520.9 & 9.93 \\
\hline Peru & 830.9 & 6.28 \\
\hline Russian Federation & 1226.8 & 11.34 \\
\hline Thailand & 1772.4 & 9.15 \\
\hline Mean (StD) & 1224.8 & 8.88 \\
& $(422.7)$ & $(2.22)$ \\
\hline
\end{tabular}

Table 8. Correlation results

\begin{tabular}{|l|c|c|}
\hline & $\begin{array}{c}\text { MVA } \\
\text { per capita }\end{array}$ & $\begin{array}{c}\text { E-waste } \\
\text { per capita }\end{array}$ \\
\hline Pearson's r & 1 & $0.693^{* *}$ \\
\hline P-value & -- & 0.026 \\
\hline
\end{tabular}


For the selected ten high-income countries (Table 9), the correlation between SDG indicators 9.2.1 and 12.4.1 changed. The correlation (Table 10) becomes negative and weak (correlation coefficient 0.173 ). The correlation is statistically insignificant (p-value 0.633). That means for high-income countries, that a country with higher MVA per capita generates less E-waste per capita, which means a higher level of industrialization is associated with greener production and consumption. Again the average MVA per capita and E-waste per capita of the ten high-income countries are much higher than countries with lower income levels as shown above.

Table 9. Descriptive data (high-income countries)

\begin{tabular}{|l|c|c|}
\hline \multicolumn{1}{|c|}{ Country } & $\begin{array}{c}\text { MVA } \\
\text { per capita }\end{array}$ & $\begin{array}{c}\text { E-waste } \\
\text { per capita }\end{array}$ \\
\hline Australia & 2835.5 & 21.68 \\
\hline Bahrain & 3632.6 & 15.92 \\
\hline Czechia (Czech Republic) & 5404.1 & 15.71 \\
\hline Israel & 4824.3 & 14.53 \\
\hline Kuwait & 2265.3 & 15.83 \\
\hline Lithuania & 3121.8 & 12.3 \\
\hline New Zealand & 4447.3 & 19.19 \\
\hline Saudi Arabia & 2753.7 & 17.57 \\
\hline Slovakia & 4172.4 & 12.76 \\
\hline Trinidad and Tobago & 2328.1 & 15.73 \\
\hline Mean (Std) & 3578.5 & 16.1 \\
& $(1091.6)$ & $(2.81)$ \\
\hline
\end{tabular}

Table 10. Correlation results

\begin{tabular}{|l|c|c|}
\hline & $\begin{array}{c}\text { MVA } \\
\text { per capita }\end{array}$ & $\begin{array}{c}\text { E-waste } \\
\text { per capita }\end{array}$ \\
\hline Pearson's r & 1 & -0.173 \\
\hline P-value & -- & 0.633 \\
\hline
\end{tabular}

To briefly summarize the empirical results, this article finds that the interaction between SDG indicators 9.2.1 and 12.4.1 varies across countries with different income levels. Although in general a country with higher MVA per capita also generates more E-waste per capita, this is not necessarily for all countries, especially for high-income countries. However, on average, with ane increase in income, the average MVA per capita and E-waste per capita increase, so that we can see that high-income countries have both the highest MVA and E-waste per capita, and vice versa for low-income countries.

\section{Discussion and conclusion}

This article uses empirical evidence from a UN data source to explore the interaction between industrial development and environmental protection dimensions of SDGs, specifically the SDG indicators 9.2 .1 and 12.4.1, by analyzing the correlation between MVA per capita and E-waste per capita in 40 countries with different income levels. For the two specific questions outlined in the introduction, this article finds that the expected negative correlation between MVA per capita and E-waste per capita only weakly and insignificantly exists in high-income countries. For low-income and upper-middle-income countries, the correlation between these two indicators is positive, strong, and statistically significant. For lower-middleincome countries the correlation is still positive, but is neither strong nor statistically significant. Therefore, the interactions between these two SDG indicators vary across countries with different income levels.

This article generates evidence to partially support the Environmental Kuznets Curve (EKC), which argues that the relationship between economic development and environmental protection follows an 'inverted U shape'. That means, at the low level of incomes, the economic development is accompanied by declines in environmental quality (e.g., more resource consumption, waste generation and pollution), but with the growth in incomes, the relationship changes and economic development leads to better environmental protection (e.g. STERN, 2017). This article found that, except uppermiddle-income countries, the positive association between MVA per capita and E-waste per capita becomes weaker and finally turns negative for high-income countries. This is possibly because high-income countries, which usually have strict enforcement of environmental protection and a more knowledge/technology-intensive growth mode, industrial development, can better promote greener production and consumption. Whereas in contrast, in those countries at low and/or lower-uppermiddle income levels, the growth modes are largely resource extensive and there are insufficient capacities (such as human capital and technology) for them to promote greener production and consumption, thus industrial development is more often associated with heavier pollution and consumption of resources.

This article also generates a number of scientific and practical implications. Firstly, it provides evidence that the analysis of SDGs and the interactions between different SDGs (including targets and indicators) should take the regional and national context into consideration, as the country context affects the achievement of, and interactions between, SDGs (e.g. LIU, 2020). Secondly, in addition to national data sources, which mainly have information on the SDG performance in 
specific countries, international data sources such as the Global SDG Indicators Database and the UNIDO Statistics Data Portal, can provide global data which enables comparisons between countries. This would be helpful for future studies on SDGs at international and regional levels.

Secondly, the interactions, integration, and tradeoffs between SDGs may coexist with each other, which calls for a more holistic, interdisciplinary, and cross-departmental monitoring, management, and research of different SDGs (including targets and indicators). The current monitoring and management of SDGs at national and international levels still has a distance to optimality. At international level, industrial development and environmental protection SDG indicators are mainly under the custody of UNIDO and UNEP respectively, with the coordination of UN Statistics Division to include relevant data into the Global SDG Indicators Database. At national level, for example, in many countries, the environmental protection SDG indicators are mainly monitored by ministries protecting the environment and resources, while industrial development indicators are mainly managed by ministries specialized in industries, economic growth, business, and/or trade. These ministries do not regularly exchange information with each other. Although the reform towards the more holistic, interdisciplinary, and cross-departmental management of SDG indicators could be a challenge for many countries, an improvement of cross-ministry cooperation and enhancement of interdisciplinary expertise could still be expected. The UN Statistics Division's efforts in cross-agency coordination and developing the Global SDG Indicators Database could be a good example of cross-departmental cooperation

This article is not without limitations, which leaves spaces for future exploration in this area. Although the article has some evidence to support the EKC, it does not go further to find out the 'turning point' of the EKC. Therefore, future studies can put more efforts to explore the 'turning point' of the EKC with more empirical data and sophisticated methods. Also, although with a lot of effort in selecting countries, the intra countrygroup (e.g. countries at the same income level) disparities in industrial development and environmental protection still exists, which may affect the correlation results in the data analysis. In future, it may also be interesting to conduct further analysis of SDG interactions across different regions. For example, a comparison between the interactions among different SDG indicators in Africa and Asia may generate more interesting insights and implications as well.

\section{Acknowledgements}

The author would like to express their sincere appreciation to the insights from former students, peers, and colleagues at the University of Oxford and UN (including its departments or agencies) such as UNIDO. The article is the author's independent research output and not the work output of any academic institute or the UN (including its departments or agencies). Unless otherwise stated, the views expressed in this article are the author's and do not reflect the official stance of any academic institute or the UN (including its departments or agencies).

\section{References}

Adshead D., Thacker S., Fuldauer L.I., Hall J.W., 2019. Delivering on the Sustainable Development Goals through long-term infrastructure planning. Global Environmental Change, 59: 1-14.

Baldé C.P., Wang F., Kuehr R., Huisman J. 2015. The global e-waste monitor - 2014. United Nations University, IAS - SCYCLE, Bonn.

Biermann F., Kanie N., Kim R.E. 2017. Global governance by goal-setting: the novel approach of the UN Sustainable Development Goals. Current Opinion in Environmental Sustainability, 26-27: 26-31.

Le Blanc D. 2015. Towards Integration at Last? The Sustainable Development Goals as a Network of Targets. Sustainable Development, 23, 3: 176-187.

Dias C.M.M., Rosa L.P., Gomez J.M.A., D’Avignon A. 2018. Achieving the sustainable development goal 06 in Brazil: The universal access to sanitation as a possible mission. Anais da Academia Brasileira de Ciencias, 90, 2: 1337-1367.

Diaz-Sarachaga J.M., Jato-Espino D., Castro-Fresno D. 2018. Is the Sustainable Development Goals (SDG) index an adequate framework to measure the progress of the 2030 Agenda? Sustainable Development, 26, 6: 663-671.

Hák T., Janoušková S., Moldan B. 2016. Sustainable Development Goals: A need for relevant indicators. Ecological Indicators, 60: 565-573.

ICSU and ISSC. 2015. Review of targets for the Sustainable Development Goals: The science perspective. International Council for Science, Paris.

Kumar A., Holuszko M., Espinosa D.C.R. 2017. E-waste: An overview on generation, collection, legislation and recycling practices. Resources, Conservation and Recycling, 122: 32-42.

Kynčlová P., Upadhyaya S., Nice T. 2020. Composite index as a measure on achieving Sustainable Development Goal 9 (SDG-9) industry-related targets: The SDG-9 index. Applied Energy, 265: 1-12.

Liu S. 2020. Interlinkages between Indicators of Sustainable Development Goals : Evidence from Seven Low Income and Lower Middle-Income Countries. Sustainable Development Research, 2, 1: 58-63.

Luken R., Mörec U., Meinert T. 2020. Data quality and feasibility issues with industry-related Sustainable Development Goal targets for Sub-Saharan African countries. Sustainable Development, 28, 1: 91-100.

Nilsson M., Griggs D., Visbeck M., Ringler C., Collum D. 2017. Introduction a framework for understanding Sustainable Development Goal interaction. [in:] D.J. Griggs, M. Nilsson, A. Stevance, D. McCollum (eds) A Guide to SDG Interactions: from Science to Implementation, International Council for Science, Paris: 18-30.

Nilsson M., Griggs D., Visbeck M. 2016. Policy: Map the interactions between Sustainable Development Goals. Nature, 534(7607): 320-322. 
Ouyang P., Fu S. 2012. Economic growth, local industrial development and inter-regional spillovers from foreign direct investment: Evidence from China. China Economic Review, 23, 2: 445-460.

Sachs J.D. Schmidt-Traub G., Mazzucato M., Messner D., Nakicenovic N., Rockström J. 2019. Six Transformations to achieve the Sustainable Development Goals. Nature Sustainability, 2, 9: 805-814.

Schroeder P., Anggraeni K., Weber U. 2019. The Relevance of Circular Economy Practices to the Sustainable Development Goals. Journal of Industrial Ecology, 23, 1: 77-95.
Stern D.I. 2017. The environmental Kuznets curve after 25 years. Journal of Bioeconomics, 19, 1: 7-28.

Tosun J., Leininger J. 2017. Governing the Interlinkages between the Sustainable Development Goals: Approaches to Attain Policy Integration. Global Challenges, 1, 9: 1-12.

UNIDO. 2019. Competitiveness Industrial Performance Report 2018: Biennial CIP Report, edition 2018. UNIDO, Vienna.

World Bank. 2020. World Bank Country and Lending Groups. Available at: https://datahelpdesk.worldbank.org /knowledgebase/articles/906519-world-bank-country-andlending-groups. Accessed June 2020. 